\title{
Understanding Islamic Dialectics in The Relationship with Local Culture in Buton Architecture Design
}

\author{
Muhammad Alifuddin \\ Institut Agama Islam Negeri Kendari, Sulawesi Tenggara, Indonesia \\ email: proposalalif@gmail.com \\ Alhamuddin \\ Universitas Islam Bandung, Jawa Barat, Indonesia \\ email: alhamuddinpalembang@gmail.com \\ Andri Rosadi \\ Universitas Islam Negeri Imam Bonjol, Sumatra Barat, Indonesia \\ email: rosadi96@yahoo.com \\ Eko Ariwidodo \\ Visiting Scholar, Fakultät für Philosophie und Bildungswissenschaft, \\ Universitäts Wien, Austria \\ email: ekarwdd@gmail.com
}

\begin{abstract}
This study aimed to describe the shape and meaning of the architectural design of the Buton house both from an emic and ethical perspective. The focus of the problem was: (1). What was the shape and pattern of the house layout of the Butonese people? (2). What was the meaning of the traditional house architecture of the Butonese people? The data were obtained through a series of interviews, non-participant observation, and document review. All data were analyzed through some stages: formulation of questions, making descriptive narratives, data reduction, application, and interpretation, then concluding. Based on an analysis of the research problem, the following conclusions were obtained: (1). The shape of the Buton house had an aesthetic meaning related to belief or the dimension of religiosity, in this case, Islam; (2). The patron or pattern of
\end{abstract}

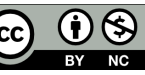

DOI: 10.19105/karsa.v29i1.3742 
the Butonese house building had become part of their system of thinking, so that eventually it became something standards, such as the standard of spatial structure, shape, structure, and ornamentation. In subsequent developments, there appeared to be an internal effort by the Butonese to provide a new perspective on the meaning of the Buton house, leading to interpretations oriented to Islamic values. The form of houses on stilts as depicted in malige and kamali by the local community was interpreted as a replica of a Muslim performing the prayer ritual. The model of a tiled roof was analogous to the composition or position when he was praying, where the place of the right hand was above the left hand. Whereas in the perspective of political power, the tiled roof was a symbol of political and religious unity. Pineapple ornaments played a role as a symbol of monotheism. This symbol also is a manifestation of the religious ethics Butonese, who always direct their life to the values of monotheism.

[Penelitian ini bertujuan mendeskripsikan bentuk dan makna desain arsitektur rumah Buton baik dalam perspektif emik maupun etik. Fokus permasalahannya yaitu: (1). Bagaimana bentuk dan pola tata ruang rumah Orang Buton?; (2). Apa makna yang terkandung arsitektur rumah tradisional Orang Buton. Sumber data penelitian ini diperoleh melalui serangkaian wawancara, observasi non-participant, dan telaah dokumen. Seluruh data dianalisis melalui tahapan; perumusan pertanyaan, membuat narasi yang bersifat deskriptif, reduksi data, eksplikasi dan interpretasi kemudian mengambil kesimpulan. Berdasarkan hasil telaah terhadap masalah penelitian dapat diperoleh kesimpulan sebagai berikut: (1) Bentuk rumah Buton memiliki makna estetika yang terkait dengan kepercayaan atau dimensi religiositas dalam hal ini Islam; (2). Patron atau pola bangunan rumah Orang Buton telah menjadi bagian dari sistem cara berpikirnya, sehingga menjadi sesuatu yang baku, seperti patokan terhadap tata ruang, bentuk, struktur bangunan, maupun ornamennya. Perkembangan selanjutnya tampak ada upaya dari internal Orang Buton untuk memberi perspektif baru dalam memaknai rumah Buton, yang mengarah pada interpretasi dengan berorientasi pada nilai-nilai Islam. Bentuk rumah panggung sebagaimana yang tergambar pada malige dan kamali oleh masyarakat setempat dimaknai sebagai replika seorang muslim yang sedang menjalankan ritual salat. Model atap bersusun dianalogikan sebagai susunan atau posisi seorang muslim ketika sedang melakukan ibadah shalat, yakni posisi tangan kanan berada di atas tangan kiri. Sedangkan dalam perspektif kekuasaan politik, atap bersusun merupakan simbol kesatuan politik dan agama. Ornamen nanas sebagai simbolisasi tauhid. Simbol tersebut sekaligus merupakan perwujudan etik religius Orang Buton yang selalu mengarahkan hidupnya pada nilai-nilai tauhid.]

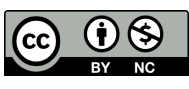

DOI: $10.19105 /$ karsa.v29i1.3742 
Keywords: Islam; local wisdom; Buton architecture

\section{Introduction}

Conceptually, home architecture that grows in the tradition of Indonesian tradition is different from residential architecture in the West. The form presented in traditional residential architecture in Indonesia is always related to the meaning of "deeper", which is represented by the look, not stopping only in the written or visible. The design, form, and especially the pattern of the existing space are to accommodate daily physical activities and spiritually to obtain inner peace or soul. ${ }^{1}$

Various research and studies on the formation of architectural designs in the archipelago show that the shape of a building is always determined by factors of geography, climate, local culture, and the beliefs held by a community. In addition, architects of the archipelago cannot escape from a development model and mixing forms from places and times. This condition also occurs in Archipelago Islamic architecture, for example, a mosque that is experiencing quite complex developments because the tendency to include regional culture (vernacularism) is very difficult to avoid. Bearing in mind that before Islam stepped on the archipelago, this country already had a local cultural style that Hinduism and Buddhism influenced. The opposite also happened, namely when Islam established its influence in the archipelago. Islamic values later influenced the various forms of buildings that were local. Departing from this perspective, the writer was interested in studying in-depth the architectural design of home buildings that grew in the historical space of the Butonese community, intending to uncover the meaning and or how the community related to interpreting the house in an architectural design space that lived in the Butonese tradition.

\footnotetext{
${ }^{1}$ Ni Ketut Agustina Dewi, "Wantah Geometri, Simetri, dan Religiusitas pada Rumah Tinggal Tradisional di Indonesia," Jurnal Permukiman Natah 1, no. 1 (2003): 29-43, https://ojs.unud.ac.id/index.php/natah/article/view/2923.
}

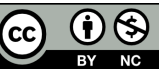

DOI: 10.19105/karsa.v29i1.3742 
In the mainstream of architectural thought, the architectural design of traditional societies is termed "vernacular" architecture. Several academics have researched related matters. ${ }^{2}$ The results of Umar's study concluded that there was a coexistence of the concept of symbolic meaning between the Kaomu's house and the Dispenda office, but it had been modified. This study recommends that the local government explore further the functional value and symbolic meaning of Buton architecture, especially those related to the political values contained in the architectural elements of houses, to be additionally applied to every government office building. In this way, it is hoped that the architectural identity of Buton can sustainably take place and not fade with time.

Riandy Tarigan said that the meaning of a traditional house, and besides that being influenced by place also influenced by the time that surrounded by the development of human culture, can be covered by technology, knowledge, economy, and lifestyle that grow in the minds of the subjects which determine the meaning. ${ }^{3}$ Therefore, the meaning of traditional houses that develop in a high complexity depends on human aspects, place, and time, which are also influenced by global culture and environmental change. ${ }^{4}$ Even Tarigan's study was oriented to the study of meaning contained in traditional home architecture design. As will be examined in this study, Tarigan's study did not touch the realm of religious / Islamic values as the focus.

Specific studies examining the relationship between Islam and local wisdom in architectural design were conducted by Heryati and Nurnaningsih in Kearifan Lokal pada Arsitektur Vernakuler Gorontalo:

\footnotetext{
${ }^{2}$ Umar Muhammad Zakaria et al., "Koeksistensi Konsep Makna Simbolik Rumah Kaum Kaomu (Malige) dengan Kantor Dispenda Kota Baubau," Jurnal Arsitektur, Bangunan, \& Lingkungan 6, no.2 (Februari 2017): 37-46, https://publikasi.mercu buana.ac.id/index.php/virtuvian/article/view/1399.

3 Riandy Tarigan, "Membaca Makna Tradisionalitas pada Arsitektur Rumah Tradisonal," Jurnal Arsitektur Komposisi 12, no. 3 (2019): 209, https://doi.org/10. 24002/jars.v12i3.2202.

${ }^{4}$ M. Syaom Barliana, "Perkembangan Arsitektur Masjid: Suatu Transformasi Bentuk dan Ruang," HISTORIA: Jurnal Pendidik dan Peneliti Sejarah 9, no. 2 (Desember 2008): 45-60, https://ejournal.upi.edu/index.php/historia/article/view/12171.
}

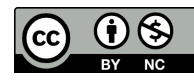


Tinjauan pada Aspek Budaya dan Nilai-Nilai Islam. This study found evidence that besides the architecture of Gorontalo houses loaded with local wisdom values, they were also determined by Islamic values. ${ }^{5}$ Likewise, the research of Zulkarnain and Andi Hildayanti had the same voice with the tittle of Integrasi Konsep Arsitektur Islam pada Rumah Adat Saoraja Lapinceng di Kabupaten Baru. The finding of this study: there were some elements of similarity in the Islamic house space pattern with the Saoraja Lapinceng traditional house space pattern, which provided clues that the teachings of Islam were integrated with the character of the Bugis tribe, which was very thick with the elements of Islamic teachings in the lives of the people. ${ }^{6}$ Even the last two studies have dealt with the relationship between local culture and Islam in architectural design, the focus of the study was still general. In contrast to this study, which focuses more on the study of meaning

\section{Methods}

This study reflects the ideas of local communities in realizing architectural designs within the dialectical frame of Islam and local culture. Operationally, this study is carried out to understand the views and meanings of the Butonese about the architectural design of homes that grow in their historical and cultural spaces. In addition to exploring the meaning of the house from an emic perspective. The study also wants to interpret the symbols contained in architectural design from an ethical perspective. Therefore, this study refers to the interpretive paradigm.

The data in this study were obtained through a series of indepth interviews, observation, and document study. To capture the rhythm and way of thinking or work patterns of cultural systems, then in this context, researchers were stimulated to study many details and place themselves in the sense of being there both intellectually and emotionally. This method was called by Geertz a thick description

\footnotetext{
${ }^{5}$ Heryati et al., "Kearifan Lokal pada Arsitektur Vernakular Gorontalo: Tinjauan pada Aspek Budaya dan Nilai-Nilai Islam," El-HARAKAH 16, no. 2 (Desember 2014): 151, https://doi.org/10.18860/el.v16i2.2774.

6 Zulkarnain AS et al., "Integrasi Konsep Arsitektur Islam pada Rumah Adat Saoraja Lapinceng di Kabupaten Barru," NATURE: National Academic Journal of Architecture 5, no. 1 (2018): 1-12, https://doi.org/10.24252/nature.v5ila1.
}

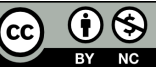

DOI: $10.19105 /$ karsa.v29i1.3742 
(interpretive anthropology); and through this method, broad conclusions will be drawn from the small but composed of tangible things. The thick description requires researchers to understand the particular culture and be directly involved with local cultural actors. ${ }^{7}$ Therefore, data analysis is carried out continuously, as long as the process is coded towards which are found based on the participant's context and perspective. ${ }^{8}$ Procedures taken, referring to the analysis mechanism developed by Miles and Huberman ${ }^{9}$ are combined with the phenomenological method of von Eckartsberg. ${ }^{10}$

\section{Results}

\section{Buton House in a Variety of Perspectives: Banua - Malige - Kamali}

The Butonese call the house the word "banua"; this word means the house in the Indonesian language as a place to stay or rest. For Butonese people, the house has a precious meaning, so it requires careful treatment by the owner. It is manifested in the form of various rules outlined by their "ancestors". Therefore, building a new house needs consultation with traditional and religious leaders. Community stratification in the Buton tradition has implications for the type of house building. In its development, the term used to refer to the house for the general public is called banua tada.

Besides Banua tada, the term Malige is also known, which is the residence of a sultan (king). There is no an extraordinary palace as an inventory of the state to the Buton Sultanate. In the perspective of the Buton tradition, a king and his descendants and the high officials of the empire did not have the inheritance of houses or palaces from the empire. ${ }^{11}$ Another term synonymous with Malige is kamali. Kamali, in

\footnotetext{
${ }^{7}$ Mudji Sutrisno et al., Teori-Teori Kebudayaan (Yogyakarta: Kanisius, 2005), 212.

${ }^{8}$ L.R. Gay et al.. Educational Research, Competencies for Analysis and Application, Sixth Edition (New Jersey: Prentice-Hall Inc., 2000), 29.

${ }^{9}$ Matthew B. Miles et al., Qualitative Data Analysis: A Sourcebook of New Methods (Beverly Hills: Sage Publication Sage, 1986), 20.

10 Clark Moustakas, Phenomenological Research Methods (London: Sage Publications, 1994), 16.

${ }^{11}$ Zadi, interview. "There was only one malige, namely Sultan Muhammad Hamidi's malige, therefore after his death, he was held with oputa yii malige. Malige was
}

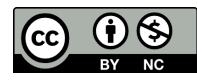


principle is the house of the Sultan and the empress. Thus Kamali is the first house of the Sultan. In the Buton tradition, in principle malige is also Kamali and vice versa, but traditionally the Butonese prefer to mention the term malige for palace purposes rather than use the term Kamali. However, if you pay attention to the initial use of the term malige as stated above, then Kamali is actually the Sultan's palace because in this place, the empress resides. In terms of construction, malige, and Kamali, besides having similarities, they also have differences. The same characteristic between malige and Kamali can be seen in the form of a cone-shaped roof like an umbrella or a meru patterned building. This form is an architectural heritage that was born before Islam.

Specifically, the shape of the roof of the malige is four-tiered, while another characteristic of the specificity of the malige is the supporting pole (the cambero), which is fan-shaped (or two struts). The difference between the two is that malige consists of four or more than two levels, while Kamali is only two levels. Throughout Buton history, there has only been one maligi, the maligi built by the $37^{\text {th }}$ Sultan LaOde Hamidi. Another characteristic that distinguishes ordinary houses from noble houses lies in the number of side poles. The number of public houses is four, six for imperial officials, and eight for the Sultan. According to the construction of the supporting pole, the houses of the aristocratic group use a fan-shaped pole while the ordinary houses only use one pole. ${ }^{12}$ Ornament in the palace use the country's symbols,

actually the residence made by Sultan Hamidi as the residence of his wives except for the empress, or in other words, malige is the second house of the Sultan". Mujazi, interview. "According to Hazirun, malige is a house inhabited by high-ranking officials of the empire so that it is not only a sultan who lives in this house. Malige, which is called a palace or a high official's house, is a house occupied by an official of the empire that he built himself before he was appointed as an official, or a house that was built after someone was appointed as an official of the sultanate and or is crowned as a sultan. A number of officials whose house or residence is called malige are; Sultan, Sapati, Kinepulu, Lakina Badia Lakina Sura Wolio, two Kapitalao people and two Bontogena people."

${ }^{12}$ Ni Ketut Agustina Dewi, "Wantah Geometri, Simetri, dan Religiusitas pada Rumah Tinggal Tradisional di Indonesia," Jurnal Permukiman Natah 1, no. 1 (2003): 29-43, https://ojs.unud.ac.id/index.php/natah/article/view/2923.

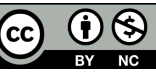

DOI: $10.19105 /$ karsa.v29i1.3742 
namely pineapple, and dragon, while the official's house is only allowed to use bosu-bosu, while banua does not use ornaments at all.

\section{The Structural Elements of the Buton House}

Buton House is formed from the core elements, which are the parts that must be present in every home, as a follows:

(a). The roof, generally in the form of a saddle, its shape and design are on the left and right (next to one side), and use natural materials. This roof frame consists of several parts, which are arranged together to form a pyramid. The elements that make up the architectural framework of the Buton are tutumbu (pole), kasolaki, pana-pana, kumboho (ridge), lelea, tadana tutumbu or sule ngalu, and tora-tora. If the house building consists of 4 levels, such as a malige building, then the building also needs four sets of roof frames. Installation of the roof of the house is not done haphazardly. The roof is arranged by taking the symbol of the position of someone's hand when praying, that is, the right hand above the left hand. On that basis, the roof of the traditional house of Buton is installed or arranged to start from the right side of the front of the house, then to the rear, then continued to the left side, and ended in front of the house. ${ }^{13}$

(b). Pole, the wooden poles are large, approximately the size of $10 \times 18 \mathrm{~cm}$, This function is to hold the house. The poles are perforated by using a chisel, starting from the central pole and then followed by the other pillars. After all, the main pillars have been perforated; they are arranged by connecting one pole to the other with the wooden pole (peg), so that a house frame is formed.

(c). Kayi or connecting beams. The orientation of the kayi is as a link between one pole with another pole.

(d). Tumbu tada, like kayi, tada tumbu is also in the form of a long flat beam that serves to tie or connect a row of poles that line to the side. Kayi and tumbu tada are based on prophetic ethical values, which state that: believers and other believers share one body that reinforces one another.

${ }^{13}$ (Andjo, 1999:43)

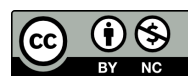


(e). The walls, walls of traditional Buton houses are made of teak, danga (jackfruit), and wola (biti) boards arranged transversely. Strengthening the relationship between one board and another is done by attaching a wooden plank to the wall on the tuorana rindi (wall frame). The wallboard of the hose attaches directly to the outside of the house pole. Rindi or wall is the center of the house that serves as a cover for all the center framework of the building (body) of the house.

(f). The door, Buton house only has two entrances at the front of the house leading into the front room and one kitchen door located on the side.

(g). Besides the window located on the front, the window is also on the left and the right side, and the facade forms a rectangular window.

(h). The floor is the bottom or base (base) of a room or building that is functionally oriented as a place to do various activities in the house. The floor of the house where the Sultan's official residence, especially the Sultan's house, is made of teak wood, wola (bitti) is a symbol of the Sultan's social status, which symbolizes the Sultan's personality as a nobleman and person who is always calm, strong and resilient in facing various social and political problems in his domain.

(i). The joint, a wooden house pole that is not directly in contact with the ground but is above the joint; namely, the foundation made of river stone (river) or flat-shaped mountain stone.

(j). Galaga, which is a flat beam placed between the tumbu tada. Thickness and width are the same as the size of the tumbu, while the length is adjusted to the length of each space. Galaga usually uses spinach wood to function as a platform or floorboard brace.

(k). Garaga, is namely parts of bamboo mounted transversely above Galaga. Garaga is only used if the floor of a house is made of bamboo. If the floor of a house uses wooden planks like in a malige building, then just galaga is enough.

\section{The Shape of the Buton House}

Buton house design is on stilts, the choice of stilt houses is closely related to the character of an agrarian society. Stilt house construction means the entire building space is built floating above the ground. This form may be an expression of the mental attitude of the Butonese, who realize the existence of humanity as a "noblest" creature

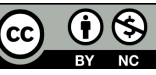

DOI: $10.19105 /$ karsa.v29i1.3742 
that must be above and overcoming nature. In the building, various rooms are created as a limiting space between something public and private in nature. In this room or space, a human dwells who does not want to just touch or be thrown at the level of the land (nature), but here it is seen that there is a form of self-esteem that is truly literal (or figuratively) overcoming nature, while respecting nature because it does not control the land surface in a greedy way. ${ }^{14}$ The choice of the model is also the response of the Butonese in prior time to the humid tropical climate. Therefore, lifting the floor from the ground is a creative choice to protect the house's occupants from tropical humidity that tends to be unfriendly and potentially decomposes natural materials.

Floating space allows free air circulation to flow and infiltrate under the floor, making the floor safe from the threat of moisture while making the space above it dry. This fact is very logical, proving that the local wisdom of traditional societies is not always built on the foundation of baseless myths. Likewise, the choice of the saddle roof model shows the balance between the right and left sides, where the roof model is formed in two levels. The body shape of the Buton house has its peculiarities, which is different from other traditional house forms. One characteristic of the Buton house, as we can see up to now, is that the design consists of more than one-story house. The second floor, for example, is on the right and left sides, which are commonly called sasimbiri tangkebala. There is also a room called pa bate and $p a$ malanga, both of these spaces serve as a place to store goods as well as an education room for teenage girls to prepare them for life by learning to gather and knit weaving yarn. The other side of Buton architecture is the ornamentation of flora and fauna such as pineapple, which is at the top of the building, thus with dragon animal ornaments. On the left-right side, there are also bosu-bosu ornaments, all of which have cultural significance that will be explained in the next discussion.

\section{Spatial Patterns}

\footnotetext{
${ }^{14}$ Maria Hidayatun, Hakekat Ruang dalam Arsitektur Tradisional Sebagai Satu Bentuk Jawaban dari Tantangan Alam (Studi Tentang Arsitektur Tradisional Vernakular) (Surabaya: Fakultas Teknik Universitas Petra, 2008), 67.
}

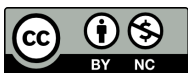


The pattern of distribution or spatial layout in the architectural design of Buton, especially the Kamali, malige or banua buildings cannot be separated from the agreed cultural values and has now become the world view of the Butonese. The Kamali and malige spatial arrangement seem to consist of tarali (terrace room), Bamba (guest room), tanga (family room), suo, sasambiri and kitchen. The core space for the design of Butonese house consists of 3 (three) parts; the front living room (Bamba), tangah (central room), and suo. Specifically for the last term, suo is "room", a special room for girls who have been puberty. Before entering Bamba, at the front, there is a terrace or tarali, a place to receive guests, which is reached by climbing the stairs. Each room has a function based on rules that apply to the local community. Bamba Ogena, for example, is a room intended to serve guests. If a house is visited or a guest arrives, which in Buton is called odaga or mia $u m b a$, they are accepted in Bamba.

The other room is the kitchen, whose position is on the backside adjacent to sasimbiri. The kitchen and toilet in the construction of the architectural building of the Buton house do not merge with the main body of the house, and the floor structure is lower than the floor of the main building. A stairway to reach it is made that connects the main house to the place. The separation of kitchen and toilet space is symbolically interpreted as the outside world, which is analogous to the disposal of the human body. In the kitchen, there is a special room made for food storage. This space, according to Mujazi is a place where a woman carries out her feminine duties, according to him; in the Buton community, there is a division pattern of labor between men and women, if men generally work outside the home such as farming or as fishermen, while women generally carry out their duties in the kitchen.

\section{Discussion}

\section{Symbolic Interpretation of the Buton House}

In this section, we will try to uncover what the meaning of the Butonese house is, in two perspectives, namely emic and ethical. In the following, all the phenomenological data that the researcher has described previously will be poured into several sections that the researcher considers important to be interpreted.

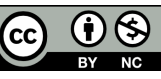

DOI: 10.19105/karsa.v29i1.3742 
According to Mujazi, the home for the Butonese is personified as human. This is reflected in the making of the floor of the room at the Butonese house is not at the same height. One room to another is uneven, or similar to the "split level" system. In the Buton house, the unevenness of the floors reflects the characteristic of humans who have breathing up and down, so that the space between one room and another is identified with the rise and fall of human breath. Viewing the house as a personification of the body and its inhabitants as a spirit shows the clarity of the vision of the Buton traditional architecture, which is different from the vision that underlies the design of architect's work that accentuates individualistic artistic value. As developed in today's modern era, architectural design solely considered as an expression of the taste of beauty. The meaning of a house that is likened to "human" shows that the house is valuable, so that it requires careful maintenance and careful treatment.

The choice of house on stilts by the Butonese in the past was inevitable from the influence of humid tropical climate conditions. This condition gives a signal to human logic to engineer the design of a house that is oriented to seasonal changes as a result of environmental character. ${ }^{15}$ The shape of the stage that dominates the building system on Buton land has technical and symbolic functions. Technically, a stilt house has 3 (three) functions: 1). Does not interfere with the water catchment field; 2). The pit space is as a medium of space conditioning with air flowing crosswise both for warmth (at night) or coolness (during the day); and, 3). From the function, the pit is also used to store supplies of firewood and others.

Mulder, as quoted by Koentjaraningrat, says that the existence of aesthetic concepts as a form of abstract ideas is always influenced by the experience of each individual and the collective experience experienced by certain groups of people. This experience includes: the development of a belief in power and higher power; social relations with other people or groups; expression of individual personality to the

15 Maria Hidayatun, Hakekat Ruang dalam Arsitektur Tradisional Sebagai Satu Bentuk Jawaban dari Tantangan Alam (Studi Tentang Arsitektur Tradisional Vernakular) (Surabaya: Fakultas Teknik Universitas Petra, 2008), 69.

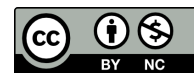


surrounding community; exploring the meanings that can be accepted by the environment. ${ }^{16}$ Referring to the perspective above, then in principle, the orientation of the Butonese building in the form of a stand is not merely aimed as explained by Tahir as I quoted. The explanation above does have a logical meaning, but the orientation of the house in the form of a stand as witnessed in the architecture of Buton does not merely stand on logic to maintain the durability of materials that are susceptible to moisture and can be attacked by termites, but also related to the values of local wisdom even the trust factor.

The spaces built hovered above the ground in the architectural house of Buton, denotatively are an expression of the dignity of the Butonese people to overcome nature, (stemming from the sun, rain and the threat of wild animals). However, connotatively, the choice of a stand design house, is at the same time an expression of respect for nature because it does not control and exploit the land surface greedily. Through the symbol of the houses on stilts, the Butonese people seem to want to state that the land they use is a platform to stand on, without having to cover it completely, and this certainly shows the wisdom of the soul of the Butonese. It can further be explained, that the choice of houses on stilts by the Butonese people may be determined by the cosmological view of the citizens of the archipelago, which divides nature into three levels, namely the upper world, the middle world and the underworld.

Indonesian pre-modern society generally understands the symbolic function of stilt houses is closely related to the fundamental beliefs of ancestral heritage, which divides the world into the lower, middle, and upper worlds. The middle world is the epicenter of the universe, and humans place themselves in the vortex of the epicenter, which is why humans choosing the space for their life tend to be in the middle, not in the underworld (earth) and top (sky). From this symbolic meaning, the structure is made a pole that functions as a separator of the whole house with the underworld and above. However, during the interview with several informants, the writer did not find any explanation about the symbolic meaning of the houses on stilts as a separation between the upper, middle, and lower worlds. The general

${ }^{16}$ Koentjaraningrat, Pokok-Pokok Antropologi Sosial (Jakarta: Dian Press, 1985).

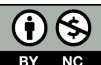

DOI: $10.19105 /$ karsa.v29i1.3742 
description that we got from traditional, religious, and cultural figures indicates the concepts and interpretations that lead to the values of Islamic traditions. For the Butonese, the form of houses on stilts as depicted in malige and kamali by the local community is interpreted as a replica of a Muslim who is performing the prayer ritual.

\section{Typology and Characteristics of Buton House}

The shape or typology of a gable in the shape of a mountain or in pre-modern architectural concept is called the meru model. The concept of meru in the Hindu era is a parallelism with the pre-Hindu era, which considers ancestral spirits to originate from the mountain and returns to the mountain. ${ }^{17}$ However, along with the times, the historical or genealogical roots of the use of the Meru model's roof have undergone a reintegration process. Butonese, as a community that is in a space and cultural circle continuing to develop are creatively active to interpret or give different meanings of a symbol. For example, the tiled roof which was originally a symbol of the beliefs of Hindus in the Astadikpalaka gods who guarded Mount Mahameru, was given a new meaning in accordance with the cultural context and values adopted by the Buton people.

For the Butonese, the model of a tiled roof is analogous to the composition or position when they are praying, where the right hand's work is above the left hand. Whereas in the perspective of political power, the tiled roof symbolizes political and religious unity in the system of power in the Sultanate of Buton. On the right and left sides of the ceilings, an elongated box is functioning as a cubicle or warehouse. The shape of the box indicates the Sultan's responsibility towards the benefit of the people.

\section{Space Organization}

The form and organization of space in this context are the arrangement of the structure of residential space organization that can be seen in its layout as a place to carry out activities, both personal and

${ }^{17}$ Abay D. Subarna, Diskusi Ilmiah Arkeologi (Jakarta: Depdikbud, 1987), 96.

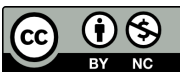


communal. In this case, the form is more directed to the type of housing that is commonly used and better known by certain communities.

Gender classification (women and men) in the Butonese home architecture implementation can be seen in the division of residential space called tetengkala. The position of the men's room is located at the front, while the women's room is at the back and second floor. The following is a matrix of spatial classification on the basis of gender in Butonese homes.

Tabel 1

Spatial Classification of Butonese Home

\begin{tabular}{|l|c|l|l|l|}
\hline $\begin{array}{c}\text { Women } \\
\text { Room }\end{array}$ & $\begin{array}{c}\text { Family } \\
\text { Room }\end{array}$ & $\begin{array}{c}\text { Living } \\
\text { Room }\end{array}$ & \multicolumn{1}{|c|}{$\begin{array}{c}\text { Education } \\
\text { Room }\end{array}$} & $\begin{array}{c}\text { Public } \\
\text { Room }\end{array}$ \\
\hline Suo & Tanga & $\begin{array}{l}\text { Bamba } \\
\text { ogena }\end{array}$ & $\begin{array}{l}\text { Pa bate \& pa } \\
\text { malanga }\end{array}$ & $\begin{array}{l}\text { Sasambiri \& } \\
\text { tarali }\end{array}$ \\
\hline
\end{tabular}

The kitchen room is used specifically for women, consisting of a wife or daughter. Men can enter this room, for example, to take food when his wife and daughter work in the fields. The front room or tarali is a room for men, this room is without walls, so outsiders can walk directly to the room. The living room or Bamba Ogena is used by homeowners to receive general guests for both women and men. In front of Tarali, there is a ladder to enter the room. Tarali is a transit room in front of Bamba ogena which functions as a terrace and is an open space that is commonly used in building. Tarali and sasimbiri in the sense of the porch is a symbol of open space, so that this place is like a tree that has thick and leafy leaves, and it allows people underneath to enjoy the coolness plus breathe fresh air, thus the philosophy of the making. Through tarali and sasimbiri, the occupants of the house eliminate fatigue because this place is flowed freely without any obstacles, making the atmosphere comfortable. Sasimbiri, besides being a place to chat, it is also used as a place for children to play and a place to do side jobs, such as making plaits.

The organization of space in Buton house, in principle, cannot be separated from the perspective of an agrarian society, like society in

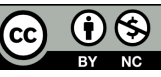

DOI: $10.19105 /$ karsa.v29i1.3742 
general, considering space is an inseparable thing from the basis of their belief in respect for nature. The soul of the Butonese is the soul of the peasant man who underlies the organization of his space on the formation of a harmonious and logical space, a combination of religious dimensions with a realistic and practical technical view and material. The arrangement of the space shows the soul of the farmer, which is divided into private (intimate) and sacred divisions. Thus, all spatial arrangements are always related to the cultural values they inherit from ancestral traditions or customs as well as related to the foundations of belief. The inner and outer regions, between social openness and closedness (closed intimacy), the family obtains a harmonious and dialectical unity between the personal life and the community, which is very balanced. This shows that the creation of harmony between the vertical relationship to the Supra power and the horizontal power to fellow beings.

\section{Cultural Symbols and Norms in Buton Architecture}

The architectural firm of the Butonese house is a personification of the human body that has a head, body, legs, and heart. The roof of the house is analogous to the human head; the body is analogous to the body of the house; the foot is analogous to the bottom or under the house; and the heart is analogous to the center of the house. The shape of the roof is arranged in a tenuous distance between Kamali and malige, indicating that the political power system in Buton does not separate religion and politics. The symbolization of the two-tiled roof represents the Sultan as a political leader as well as a religious leader.

The number of rooms in the body of the house is five, seven or nine. The symbol of the number of rooms that must exist in Kamali or malige means that the Sultan as a servant of God who holds the mandate of power must embody the teachings of Islam in his government. Five rooms are analogous to the five pillars of Islam, seven are analogous to the number of verses of the Surah Al-Fatihah, and nine are the same as the nine heavens. The reality of split level in Buton house architecture in which the front, middle, and rear floors are uneven, especially in the right side of the house. The more backward the higher, which is analogous to the position of people praying. Another meaning of split

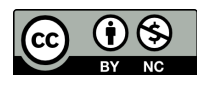

DOI: $10.19105 /$ karsa.v29i1.3742 
level as stated by Mujazi; is a symbol of human nature that has a breathing up and down.

At the top of the house, there is a pineapple symbol that has a sacred and profane meaning. Pineapple is a personification of a unique fruit, this plant is the only type of plant that has one stem and one fruit. From a religious perspective, this plant is a symbol of belief in monotheism, as well as illustrating that the belief recognized within the scope of the Buton Sultanate is only monotheistic belief (read: Islam). The profane dimension of the pineapple symbolism is that in the political sphere, there is only one Sultan who leads the country. Another uniqueness of this type of plant is that even if the leaves have died, they remain or are not separated. From the perspective of religious belief, this indicates the existence of a relationship between a prayer, the people who have died, and humans who are still alive. Whereas in the political perspective, it symbolizes the unity of the citizens of the people to the state or Sultan.

The dragon is a symbol of the might and power of the government as well as the embodiment of the genealogy of the Butonese people in terms of origin has genetic links to the mainland Chinese community. If pineapple is a symbol of prosperity that grows from the people, then the dragon is a symbol of governmental authority and tells about the origins of the ancestors of Buton from mainland China. Apart from the symbolization of the culture that has been described, in fact, there are still many meanings in the physical design elements of the Buton house architecture, those which are represented in banua tada, malige and Kamali. The building philosophical differentiation of the general public and the aristocracy is intended, so that social status and position are not reduced and even have a very decisive role in culture. The status is present in the form of buildings. The house of a Sultan, imperial officials, and even ordinary people have differences, but the differences are not significant, and they are just differentiators to show identity as a regional symbol.

The use of ornaments, which is relatively lacking, reinforces the characteristics and typology of the simple Butonese people and tends to focus more on practical life issues. The dominance of decorative patterns originating from natural forms (flora and fauna), such as fruit and animals, shows the appreciation of the Butonese for their natural

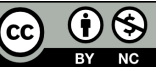

DOI: 10.19105/karsa.v29i1.3742 
physical environment, which is seen as the most beautiful blessing of ancestral heritage that must be preserved. Likewise, the symmetrical arrangement of the facade of the building also implies the characteristics of the Buton people who prioritize practicality and idealism. The symmetrical pattern is a symbol of the norm of "equality" or "honesty", which is upheld and passed down from generation to generation by the people of Buton, as well as a symbol of democratic norms.

The embodiment of the front porch or tarali, which is public, is a symbol of the cultural and social norms of the Butonese who are "open" or transparent and uphold the silaturrahim and kinship and social relations. Jar placed in front of the house as a place of water symbolizes purity of anyone entering the house ${ }^{18}$, who has a pure heart. Beside the urn located in front of the house, the urn symbol or bosu-bosu is also located in pabate and sasambiri tangkebala. This symbol, if interpreted literally, means a place of water made of clay shaped like a bowl, which means a container that holds fortune.

\section{Reading the Buton House from an Islamic Architecture Perspective}

Islamic architecture is one style of architecture displaying beauty that is rich in meaning. Every detail contains an element of symbolism with a very deep meaning. One of the meanings read on Islamic architecture is that our sense of admiration for beauty and aesthetics in architecture is inseparable from submission and surrender to the greatness and majesty of God, as the One who has all the beauty. Furthermore, when we examine it in-depth, Islamic architecture carries more on the universal values contained by Islamic teachings. These values can later be translated into architectural language. They appear in various forms depending on the context, by not forgetting the essence

18 Muhammad Zakaria Umar, "Koeksistensi Konsep Makna Simbolik Rumah Tradisional Buton (Rumah Kaum Maradika) dengan Kantor BKDD di Kota Baubau," Jurnal Teknik: Jurnal Mustek Anim HA 5, no. 1 (2016): 17-29, http://ejournal. unmus.ac.id/index.php/mustek/article/view/487.

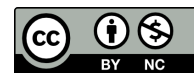


of architecture itself and sticking to the primary purpose of the architectural process, which is as part of worshiping God. ${ }^{19}$

Buton architecture is closely related to the traditions of the past or their ancestors. In some respects, it is still parallelism from the Hindu era, such as the house's symbolism on stilts refer to the cosmology of the upper-middle and the lower world. Musallah was created to function as a place of worship or meditation. Likewise, the shape of the roof, which was inspired by the concept of meru is also strongly associated with elements of Hindu belief.

However, there are many things in the spatial distribution of Buton houses, those which can honestly be stated as Islamic terms. ${ }^{20}$ Identification of the interior design of Buton's house can clearly be seen in the creation of various chambers of space called Bamba Ogena, tanga, pa', suo, sasimbiri, those which also show similar effects. The rooms mentioned above function as a barrier or assign of clarity in the function of rooms in a building, including the living room, family room, and a special room for girls. The existence of a room divider that separates the room of the opposite sex, especially the girls' room, basically has conformity with Islamic values. Normative Islamic teachings set the norms of relations between adolescent girls and sons strictly, or at least not as free as the Western perspective regulates relations between men and women.

Although initially the arrangement of the dividing space between private and public spaces is not a direct impact of Islamic teachings, basically the spatial design within certain limits can be stated as something of an Islamic dimension, bearing in mind that Islamic culture and normative traditions are based on understanding the importance of maintaining the genitals of a woman who is not worthy of being seen except by her muhrim. ${ }^{21}$ This is probably the meaning of the word

\footnotetext{
${ }^{19}$ Aulia Yahya, “Arsitektur Islam: Seni Ruang dalam Peradaban Islam,” November 4, 2008, https://auliayahya.wordpress.com/2008/11/04/arsitektur-islam-seni-ruangdalam-peradaban-islam/.

${ }^{20}$ Alhamuddin, “Abd Shamad Al-Palimbani's Islamic Education Concept: Analysis of Kitab Hidayah Al-Sālikin Fi Suluk Māsālāk Lil Muttāqin,” Qudus International Journal of Islamic Studies 6, no. 1 (2018): 89-102, https://doi.org/10.21043/qijis. v6i1.3717.

${ }^{21}$ Quran Surah An-Nur, verse 31.
}

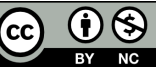

DOI: 10.19105/karsa.v29i1.3742 
"Idris", which says that; indeed, what appears from the Butonese tradition always refers to cultural values, which in principle are religion itself because the genealogical Buton people are Muslim communities. In the above context, the Butonese socio-cultural system manifested in the form and organization of the Buton home space is actually an organic unity of various elements originating from within the Buton community itself or coming from outside, as well as the implications of the influence of the time travel that surrounds them. Although the influence of foreign culture (from outside the Butonese community) on the local community's culture occurs, the relationship between these elements forms a dynamic mix. ${ }^{22}$ It happens as a result of the interaction between the elements that greet one another. In the process, an attempt is made to accept, adapt, and match local cultural elements and those coming from outside, without giving birth to significant "conflicts".

Adjustment and integration between cultural elements as described are normal and common to occur because naturally, every new element entering a cultural space is necessary to adapt to all systems that have been formed earlier, at least with basic values which exist in a cultural space before appearing as a part of the local cultural elements. ${ }^{23}$ One reality is that many communities, including Butonese cannot avoid the magnet of the earth's gravitational force. Any time leads individuals and a community to process text normativity into a domain that is more in line with the new world views and adapted to the natural environment of current culture. Whether we realize it or not, this condition has occurred in the cultural space of the Butonese people, even though it may still be individual.

Efforts to re-interpret the symbols embedded in the cultural text of the Buton by the Butonese, in principle, are now underway. Therefore, it is no exaggeration to state the socio-cultural dynamics currently taking place in the Butonese environment. One of the forms is an attempt by the related community to try to understand some of the

\footnotetext{
${ }^{22}$ Muhammad Alifuddin, Alhamuddin, and Nurjannah, "School of Anak Laut (Sea Children): Educational Philanthropy Movement in Bajo Community of Three-Coral World Center." Jurnal Iqra': Kajian Ilmu Pendidikan 6, no. 1 (2021): 164-79. https://journal.iaimnumetrolampung.ac.id/index.php/ji/article/view/1057.

${ }^{23}$ Koentjaraningrat, Pokok-Pokok Antropologi Sosial (Jakarta: Dian Press, 1985), 248.
}

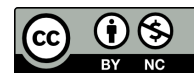


symbols contained in the Buton house text as a form of embodiment of Islamic values. For example, the meaning of pineapple ornaments is symbolized by monotheism. The interpretation is clearly a creative effort of the Butonese in interpreting the symbol of the Buton house as something that comes from the ethical embodiment of the Butonese who always directs his life to monotheistic values, even the historical roots may be that the orientation was not originally intended to make the orientation of the pineapple symbol as a symbolization of monotheism, but only ordinary profane symbols.

The meaning and association of physical symbols used to have profane symbolic meanings are very possibly not related to Islamic values. The interpretation of meanings characterized by Islamic culture is not new in the Muslim tradition in Indonesia. The closest example for this case is the interpretation of the mosque roof, both three or five steps. The three-story roof by Muslims is interpreted as a symbol of the level of religious methods, namely: shari'a, makrifat, and nature. In contrast, the five-step roof symbol is a symbol of the pillars of Islam.

The influence continuously by the great tradition (Islam) on local culture exists on the Butonese. In the context of the relationship between Islam and the local traditions of Buton, it can be seen in the historical roots based on the room development pattern, which consists of five (five pillars of Islam), seven (seven verses in Surah Al-Fatihah), and nine (sky arrangements). Belief about the orientation of the division of rooms amounting to five, seven, and nine may initially only be an ordinary architectural creation or even an ancestral tradition. However, the teachings, which were initially an ancestral tradition, are then processed in the historical space to create a color configuration or motivation. The color or bases of cosmology that were "pure" originated from the concept of profane space given the style of "Islam" by legitimizing the concept with Islamic symbols, in this case: the Five Pillars of Islam, seven verses of Surah Al-Fatihah.

Base on the analysis, it can be stated that the reality of the Islamic frame in the local wisdom of the Butonese home architecture shows the occurrence of dynamic relationships that cause changes in basic

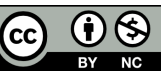

DOI: 10.19105/karsa.v29i1.3742 
concepts or motivations in some architectural designs. ${ }^{24}$ The change occurs as a result of the inclusion of Islamic traditions in the cultural space of the Buton people. Generally, changes occur slowly and are strongly influenced by the atmosphere of the socio-cultural environment of the Buton community that continues to develop. Thus, the dialectical process between Islam and local culture in Buton architectural design can be stated as a dynamic relationship and take place in harmony, and then have caused genuine local traditions to change into local Islamic traditions.

\section{Conclusions}

The shape of the Buton house has an aesthetic meaning related to belief or the dimension of religiosity, in this case, Islam. This phenomenon is seen by the presence of space and home ornament. In addition, the form of spatial composition is still trusted for the placement of women's and men's spaces, besides neutral spaces and sacral spaces. The use of the word "banua" as a house shows that this term has meaning and value, so it requires careful maintenance and careful treatment. It makes clear the importance of the home for the Butonese people. Therefore, until now, some Butonese, especially those who live around the palace area, are still faithful to follow the rules and patterns that apply, and they have been followed since ancient times. The patron or pattern of the building for the Butonese has become part of their system of thinking so that eventually it becomes something standard, such as a benchmark for spatial structure, shape, structure, and ornamentation. In subsequent developments, there appears an internal effort by the Butonese to provide a new perspective on the meaning of the Buton House elements to Islamic values. The orientation of ornamentation and the shape of the tiled roof were seen as an embodiment of Islamic ethics.

${ }^{24}$ Sidik Tono et al., "The Harmonious Relationship between Minangkabau Custom and Islam in the Distribution of Inheritance," Al-Shajarah: Journal of the International Institute of Islamic Thought and Civilization, Special Issue: Shariah and Law as Catalysts for Global Peace (2019): 39-55. https://journals.iium.edu.my/ shajarah/index.php/shaj/article/view/931.

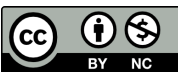


The outline of the signs manifested in the architecture of Buton House is an articulation of symbols that unfold, from spiritual ideas about the concept of God, as well as the harmony of relations between humans and humans with the natural environment as the work of God's creation or blessing. The symbols embedded in the Buton House are a picture of the idea of a democratic social system. Even social status and position were not reduced because they are not present in the form of buildings. The Buton House symbolizes a code that upholds togetherness, dynamics, and openness to cultural contacts, but it remains consistent with ancestral customs. The Buton House symbolizes harmony that is more appreciative of practical and functional things than those aesthetic-symbolic. A collection of symbols embedded in the Buton House, in principle, has universal values. In many ways, the design of the form and procedure of the Buton House has compatibility with the value of Islamic architecture. The Buton House, within certain limits, can be expressed as a portrait of Islam in the frame of local wisdom.

\section{Bibliography}

Alhamuddin, Alhamuddin. "Abd Shamad Al-Palimbani's Islamic Education Concept: Analysis of Kitab Hidayah Al-Sālikin Fi Suluk Māsālāk Lil Muttāqin." Qudus International Journal of Islamic Studies 6, no. 1 (Februari 2018): 89-102. https://doi.org/ 10.21043/qijis.v6i1.3717.

Alifuddin. Islam Buton (Interaksi Islam dengan Budaya Lokal). Jakarta: Balitbang Depag RI, 2006.

Alifuddin, Muhammad, Alhamuddin, and Nurjannah. "School of Anak Laut (Sea Children): Educational Philanthropy Movement in Bajo Community of Three-Coral World Center." Jurnal Iqra': Kajian Ilmu Pendidikan 6, no. 1 (2021): 164-79. https://journal. iaimnumetrolampung.ac.id/index.php/ji/article/view/1057.

Andjo, Nur Ikhsanuddin. Rumah Adat Buton. Majalah Budaya Buton edisi II. Kendari: Yayasan Wolio Molagi, 1999.

$A S$, Zulkarnain and Andi Hildayanti, "Integrasi Konsep Arsitektur Islam pada Rumah Adat Saoraja Lapinceng di Kabupaten Barru." NATURE: National Academic Journal of Architecture 5, no. 1 (2018): 1-12. https://doi.org/10.24252/nature.v5ila1.

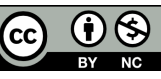

DOI: 10.19105/karsa.v29i1.3742 
Barliana, M. Syaom. "Perkembangan Arsitektur Masjid: Suatu Transformasi Bentuk dan Ruang." HISTORIA: Jurnal Pendidik dan Peneliti Sejarah 9, no. 2 (Desember 2008): 45-60, https:// ejournal.upi.edu/index.php/historia/article/view/12171.

Dewi, Ni Ketut Agustina. "Wantah Geometri, Simetri, dan Religiusitas pada Rumah Tinggal Tradisional di Indonesia." Jurnal Permukiman Natah 1, no. 1 (2003): 29-43. https://ojs.unud.ac.id/index. $\mathrm{php} /$ natah/article/view/2923.

Gay, L. R., and Peter W. Airasian. Educational Research, Competencies for Analysis and Application (Sixth Edition). New Jersey: Prentice-Hall Inc., 2000.

Heryati, Heryati and Nurnaningsih Nico Abdul. "Kearifan Lokal pada Arsitektur Vernakular Gorontalo: Tinjauan pada Aspek Budaya dan Nilai-Nilai Islam." EL-HARAKAH: Jurnal Budaya Islam 16, no. 2 (Desember 2014): 151-173, https://doi.org/10.18860/el. v16i2.2774.

Hidayatun, Maria. Hakekat Ruang dalam Arsitektur Tradisional Sebagai Satu Bentuk Jawaban dari Tantangan Alam (Studi Tentang Arsitektur Tradisional Vernakular). Surabaya: Fakultas Teknik Universitas Petra, 2008.

Kementerian Agama. Al-Qur'an dan Tafsirnya. Jakarta: Kementerian Agama RI, 2010.

Koentjaraningrat. Pokok-Pokok Antropologi Sosial. Jakarta: Dian Press, 1985.

Miles, Matthew B., and A. Michael Huberman. Qualitative Data Analysis: A Sourcebook of New Method. Beverly Hills: Sage Publication, 1986.

Moustakas, Clark. Phenomenological Research Methods. London: Sage Publications, 1994.

Tarigan, Riandy. "Membaca Makna Tradisionalitas pada Arsitektur Rumah Tradisional." Jurnal Arsitektur Komposisi 12, no. 3 (2019): 199-210. https://ojs.uajy.ac.id/index.php/komposisi/arti cle/view/2202.

Subarna, Abay D. Diskusi Ilmiah Arkeologi. Jakarta: Depdikbud, 1987. Sutrisno, Muji and Hedar Putranto. Teori-Teori Kebudayaan. Yogyakarta: Kanisius, 2005.

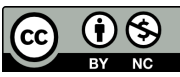


Tono, Sidik, M. Roem Syibly, Amir Mu'allim, Ahmad Nurozi, and Muhammad Roy Purwanto. "The Harmonious Relationship between Minangkabau Custom and Islam in the Distribution of Inheritance." Al-Shajarah: Journal of the International Institute of Islamic Thought and Civilization 24, Special Issue: Shariah and Law as Catalysts for Global Peace (2019): 39-55. https://journals. iium.edu.my/shajarah/index.php/shaj/article/view/931.

Umar, Muhammad Zakaria. "Koeksistensi Konsep Makna Simbolik Rumah Tradisional Buton (Rumah Kaum Maradika) dengan Kantor BKDD di Kota Baubau," Jurnal Teknik: Jurnal Mustek Anim HA 5, no. 1 (2016): 17-29. http://ejournal.unmus.ac.id/ index.php/mustek/article/view/487.

Umar, Muhammad Zakaria and Muhammad Arsyad. "Koeksistensi Konsep Makna Simbolik Rumah Kaum Kaomu (Malige) dengan Kantor Dispenda Kota Baubau." Jurnal Arsitektur, Bangunan, \& Lingkungan 6, no. 2 (Februari 2017): 37-46. https://publikasi. mercubuana.ac.id/index.php/virtuvian/article/view/1399.

Yahya, Aulia. "Arsitektur Islam: Seni Ruang Dalam Peradaban Islam." November 4, 2008. https://auliayahya.wordpress.com/2008/11/ 04/arsitektur-islam-seni-ruang-dalam-peradaban-islam/. 